János Kundrák, István Sztankovics, Martina Gévai, Miskolc, Hungary

\title{
COMPARATIVE ANALYSIS OF CBN CUTTING INSERTS WITH DIFFERENT EDGE GEOMETRIES
}

\begin{abstract}
Annotation. In this paper the experimental results of newly developed cutting inserts with special geometry and position for machining of hardened surfaces are summarized. The design of the tool holder and cutting insert allows the increase of the applied feed values in hard turning. Experiments are carried out at increased feed in bore turning procedure and the results are compared with the nowadays used conventional turning technology.
\end{abstract}

Keywords: machining of hardened surfaces; cutting material grade; cutting edge geometry; roughness; cutting forces; modeling.

\section{INTRODUCTION}

The expected functions of mechanical engineering products (like long lifetime and high reliability) and the rising quality demands for goods requires the application of more accurate machining procedures with higher productivity. From these, great emphasis is placed especially on finish machining, since this operation is essential for the realization of the prescribed quality standard of the finished manufactured part. One way to increase the lifetime is the production of hardened surfaces with proper heat treatment and machining with a suitable finishing procedure. As a result, the parts can be loaded more and can be used longer.

Abrasive (mainly grinding) procedures have been used for a long time for the machining of hardened surfaces, as the chosen accuracy could be achieved efficiently only with grinding technology. For the precision finish machining of parts with mainly hardened surfaces, nowadays many kinds of defined-edged cutting tools are available in terms of cutting material grade and cutting edge geometry $[1,2]$. The production of parts with hardened surfaces can be done properly on machine tools developed for hard turning with the expected accuracy for precision finishing $(<\mathrm{IT} 5)[3,4]$. The increasingly diverse appearance of superhard cutting materials and their rapid spread support the application of them, while increasingly strict environmental standards force the machine industry to apply procedures with defined-edged cutting tools instead of (or in addition to) the abrasive operations, where possible $[1,4]$

Though grinding it is known to produce good surface quality, a much higher material removal rate (MRR) can be achieved with hard turning [5,6], while a properly chosen cutting insert can produce the same or better surface roughness. 
A further advantage is that numerous operations can be done by hard turning with one setup and cutting tool. Example cases can be the machining of shaped parts and surface groups composed of multiple, differently oriented surfaces $[7,8]$.

It was assumed - based on the nearly 4-5 times higher material removal performance of hard turning - that the grinding procedure can be excluded [7]. However, after the analysis of suitability for functional requirements of the built-in parts, it turned out that the produced topography (periodical) by hard turning is not appropriate for numerous applications, for example surfaces displacing on each other, sealing surfaces, etc. [5,9]. Therefore, combined procedures have appeared, where the essence is to machine the surface with the two procedures - turning and grinding - in one machine tool (earlier two separate machine were needed). In this way the advantages of the two procedure can be maintained while the disadvantageous attributes can be reduced. If we work on one machine tool with one clamping, we can acquire significant economic benefits [3].

In this study combined finish machining is realized in one operation: roughing by hard turning and finishing by grinding. Our aim is to increase the efficiency of the final operation in such a way that the MRR is increased in the roughing by the usage of a novel cutting tool, which allows the application of higher secondary motion, and by the application of increased feed rates.

To achieve the acceptable quality in hard turning with the application of a novel cutting tool, one of the most important requirements must be taken into consideration: the proper rigidity of the machining mechanical system, mainly due to the high passive force [4]. Low deflection in the mechanical system is a preliminary condition to meet the required accuracy. Therefore, in this paper we study the increase rate of the cutting forces and the achievable geometric accuracy with the application of a new cutting insert.

\section{EXPERIMENTAL CONDITIONS}

Bore machining of gears is studied in the cutting experiments based on the boundary conditions of our industrial partner. After the heat treatment (case hardening), the finishing of the hard surface is done in one clamping but in two steps. The first step was carried out by rough hard turning, which is followed by the finish procedure, grinding. The aim is to exchange the roughing insert used so far by the introduction of the new eight-edged octagon insert.

In our study we applied two CBN cutting inserts (Table 1) during the rough hard turning. The standard tool used up to now (CNGA 120412, rhombic shape with $80^{\circ}$ nose angle) is marked in our study as "Insert A", while the novel cutting tool [10] is marked as "Insert B". The edges of Insert B are curved, so the sides of the octagon consist of circle sections. 
Table 1 - The studied cutting inserts

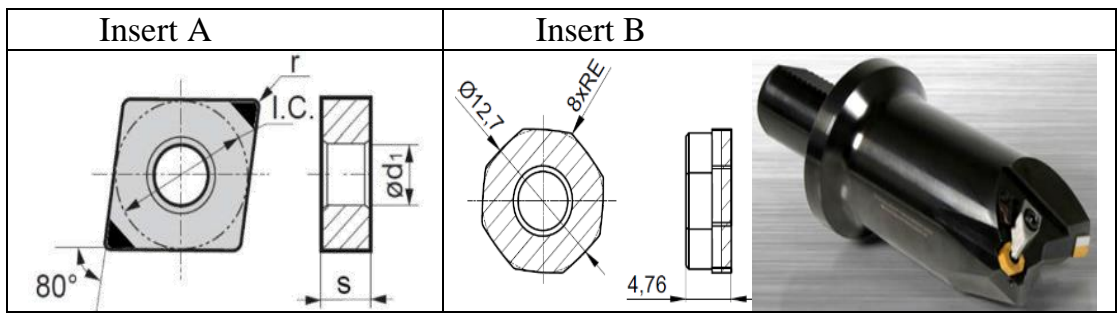

The main property of Insert $\mathrm{B}$ is the $0^{\circ}$ major cutting edge angle in the surface-generating point; however, the octagon insert is inclined by $45^{\circ}$ in the cutting edge plane, which is the inclination angle of the tool $\left(\lambda_{\mathrm{s}}\right)$. The rake angle $(\gamma)$ is $14^{\circ}$, while the nose radius $\left(r_{\varepsilon}\right)$ of the cutting insert is $28 \mathrm{~mm}$ due to the curved edge. The bore turning was done on an EMAG VSC 400 DS type hard turning machine tool.

In our study the bore (38 $\mathrm{mm}$ length and $88 \mathrm{~mm}$ diameter) on a gear is machined. The workpiece material is $17 \mathrm{CrNi6}-6$ with $62-64 \mathrm{HRC}$ hardness.

Among the cutting parameters the depth of cut is constant $0.12 \mathrm{~mm}$ in all setups for both inserts. $175 \mathrm{~m} / \mathrm{min}$ cutting speed and $0.24 \mathrm{~mm}$ feed are applied for Insert A, while nine pairs of values are determined within the cutting speedfeed rate range recommended by the insert manufacturer for Insert B (Figure 1).

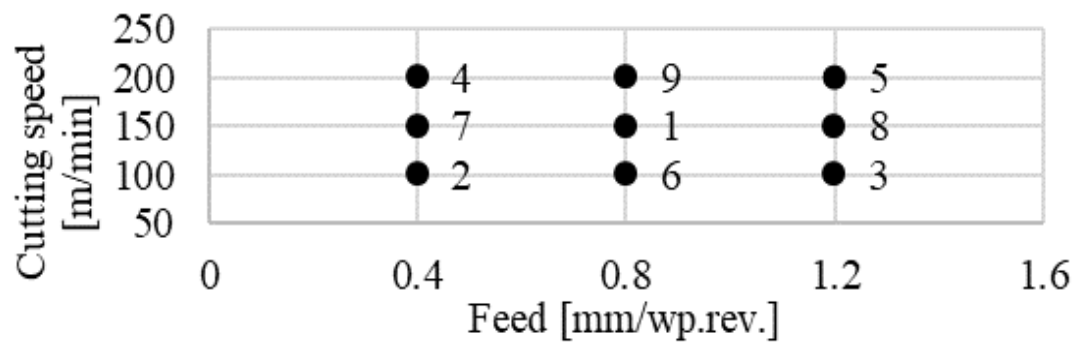

Figure 1 - Demonstration of the setups during the experiments

The cylindrical and roundness errors are measured during the experiments. The required measurements in the specified points are done by a Taylor Hobson Talyrond 365 measurement device. FEM simulations are made with ThirdWave AdvantEdge 7.5 software for the analysis of the cutting force alteration. In this study, the cutting force components are studied for both inserts. 


\section{EXPERIMENTAL RESULTS}

After the cutting experiments were carried out with the studied process parameters, the mentioned accuracy parameters (cylindricity and roundness) were measured. The FEM simulations were carried out with the same values for the analysis of the cutting forces. Lastly, we determined the machining times.

\subsection{Cylindricity and Roundness errors}

The accuracy errors were measured on all workpieces. For the cylindrical error we made measurements on 100 planes with $0.3 \mathrm{~mm}$ increment, and the following parameters were analysed [11]:

- CYLp: the peak maximum material departure from the fitted reference

- CYLv: the valley maximum departure from the reference cylinder into the material of the workpiece

- CYLt: the separation of two cylinders coaxial with the axis of the reference cylinder that just enclose the data

- CYLtt: the maximum absolute difference in diameters of the taper error

- Total run-out: the difference in the radial distances from the datum axis between the furthest and nearest point

- Coaxiality (Coax): the displacement between the reference cylinder axis and the datum axis.

- Cone angle: reflects the taper angle in the component

In Figure 2 some resulting diagrams are presented from the cylindricity measurements. The values for the 10 different setups are shown in Table 2 .

Table 2 - The measured cylindricity parameters

\begin{tabular}{|c|c|c|c|c|c|c|c|c|}
\hline Insert & No. & $\begin{array}{c}\text { CYLp } \\
{[\mu \mathrm{m}]}\end{array}$ & $\begin{array}{c}\text { CYLv } \\
{[\mu \mathrm{m}]}\end{array}$ & $\begin{array}{c}\text { CYLt } \\
{[\mu \mathrm{m}]}\end{array}$ & $\begin{array}{c}\text { CYLtt } \\
{[\mu \mathrm{m}]}\end{array}$ & $\begin{array}{c}\text { Total Run-Out } \\
{[\mu \mathrm{m}]}\end{array}$ & $\begin{array}{c}\text { Coax } \\
{[\mu \mathrm{m}]}\end{array}$ & $\begin{array}{c}\text { Cone angle } \\
{\left[{ }^{\circ}\right]}\end{array}$ \\
\hline $\mathrm{A}$ & 1 & 14.12 & 5.91 & 20.03 & 12.05 & 20.03 & 5.34 & 0.01 \\
\hline \multirow{5}{*}{$\mathrm{B}$} & 1 & 19.36 & 17.97 & 37.33 & 18.93 & 37.33 & 15.92 & 0.0263 \\
\cline { 2 - 10 } & 2 & 14.71 & 9.90 & 24.62 & 15.49 & 24.62 & 10.01 & 0.0213 \\
\cline { 2 - 9 } & 3 & 84.66 & 37.26 & 121.91 & 19.99 & 121.91 & 69.04 & 0.0183 \\
\cline { 2 - 9 } & 4 & 49.81 & 10.77 & 60.58 & 12.82 & 60.58 & 21.88 & 0.0116 \\
\cline { 2 - 9 } & 5 & 58.92 & 43.73 & 102.65 & 17.36 & 102.65 & 67.47 & 0.0324 \\
\cline { 2 - 9 } & 6 & 17.18 & 10.41 & 27.59 & 19.60 & 27.59 & 11.48 & 0.0301 \\
\cline { 2 - 9 } & 7 & 10.41 & 6.14 & 16.55 & 19.10 & 16.55 & 3.33 & 0.0277 \\
\cline { 2 - 9 } & 8 & 44.93 & 16.17 & 61.10 & 27.33 & 61.10 & 27.45 & 0.0816 \\
\cline { 2 - 9 } & 9 & 23.53 & 11.87 & 35.40 & 29.28 & 35.40 & 15.15 & 0.0638 \\
\hline
\end{tabular}


Insert A

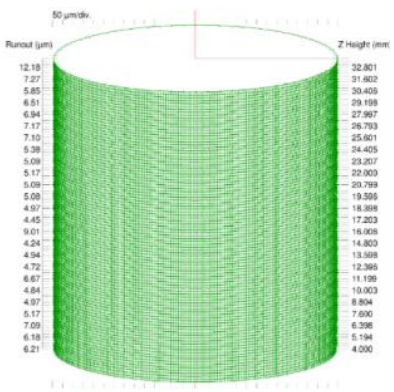

Insert B

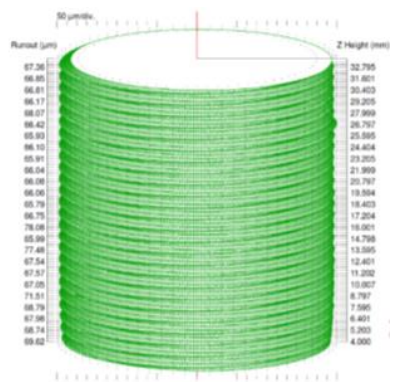

Figure 2 - Cylindricity of the bores for the rhombic (A) and octagon (B) inserts

Measurements are made at the two ends and at the middle plane of the analysed range and these values are averaged for the determination of the roundness parameters. The following parameters are evaluated [11]:

- RONp: maximum material departure from the fitted reference

- RONv: maximum departure from the reference circle into the material

- RONt: the separation of two circles concentric with the centre of the reference circle that just enclose the data

- DFTC: Departure From True Circularity, the max. radial departure in the profile

- Slope (Max/Mean): absolute value of $\mathrm{dr} / \mathrm{d} \varphi$ (r: radial departure; $\varphi$ : angle variable) at each profile points (max. and mean values are analysed)

Examples of the characteristic measurement diagrams are presented in Figure 3, while the measurement results are shown in Table 3.

Table 3 - The measured roundness values

\begin{tabular}{|c|c|c|c|c|c|c|c|}
\hline Insert & No. & $\begin{array}{c}\text { RONp } \\
{[\mu \mathrm{m}]}\end{array}$ & $\begin{array}{c}\text { RONv } \\
{[\mu \mathrm{m}]}\end{array}$ & $\begin{array}{c}\text { RONt } \\
{[\mu \mathrm{m}]}\end{array}$ & $\begin{array}{c}\text { DFTC } \\
{[\mu \mathrm{m}]}\end{array}$ & $\begin{array}{c}\text { Max Slope } \\
{\left[\mu \mathrm{m} /{ }^{\circ}\right]}\end{array}$ & $\begin{array}{c}\text { Mean Slope } \\
{\left[\mu \mathrm{m} /{ }^{\circ}\right]}\end{array}$ \\
\hline $\mathrm{A}$ & 1 & 4.24 & 3.01 & 7.25 & 5.10 & 1.20 & 0.27 \\
\hline & 1 & 6.01 & 6.83 & 12.84 & 7.41 & 4.19 & 0.98 \\
\cline { 2 - 8 } & 2 & 4.12 & 3.33 & 7.45 & 4.30 & 0.97 & 0.23 \\
\cline { 2 - 8 } & 3 & 30.14 & 11.66 & 41.80 & 30.58 & 9.35 & 2.02 \\
\cline { 2 - 8 } B & 4 & 8.05 & 6.19 & 14.24 & 7.90 & 1.60 & 0.28 \\
\cline { 2 - 8 } & 5 & 9.26 & 9.24 & 18.50 & 9.04 & 1.90 & 0.60 \\
\cline { 2 - 8 } & 6 & 5.45 & 4.92 & 10.38 & 4.28 & 1.05 & 0.37 \\
\cline { 2 - 8 } & 7 & 2.78 & 1.71 & 4.49 & 2.60 & 0.47 & 0.16 \\
\cline { 2 - 8 } & 8 & 9.62 & 11.50 & 21.12 & 11.03 & 5.41 & 1.10 \\
\cline { 2 - 8 } & 9 & 4.86 & 6.22 & 11.09 & 3.48 & 0.55 & 0.31 \\
\hline
\end{tabular}


Insert A

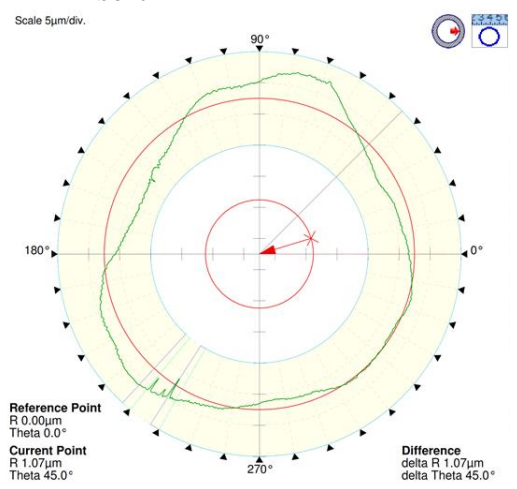

Insert B

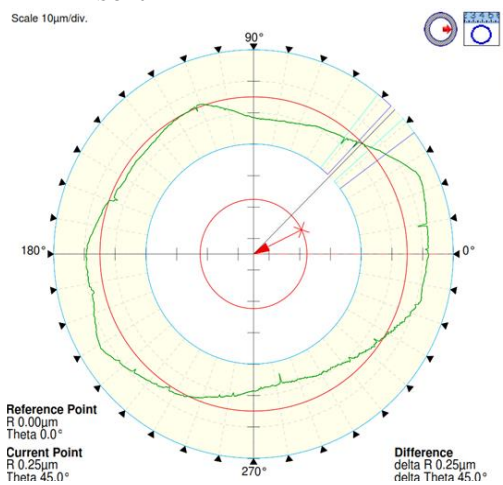

Figure 3 - Roundness of the bores for the rhombic (A) and octagon (B) inserts

\subsection{Alteration of the cutting forces}

The cutting force analysis was carried out by Finite Element Method simulations with ThirdWave AdvantEdge 7.5 software. Resulting values of the following parameters are evaluated, summarized and shown in Table 4: main cutting force $\left(\mathrm{F}_{\mathrm{c}}\right)$, passive force $\left(\mathrm{F}_{\mathrm{p}}\right)$, feed directional force $\left(\mathrm{F}_{\mathrm{f}}\right)$, required power $\left(\mathrm{P}_{\mathrm{c}}\right)$, cutting torque $(\mathrm{M})$ and cutting temperature $(\mathrm{T})$.

Table 4 - FEM results for Insert A and B

\begin{tabular}{|c|c|c|c|c|c|c|c|c|c|}
\hline Insert & No & $\begin{array}{c}\mathrm{V}_{\mathrm{c}} \\
{[\mathrm{m} / \mathrm{min}]}\end{array}$ & $\begin{array}{c}\mathrm{f} \\
{[\mathrm{mm}]}\end{array}$ & $\begin{array}{c}\mathrm{F}_{\mathrm{x}} \\
{[\mathrm{N}]}\end{array}$ & $\begin{array}{c}\mathrm{F}_{\mathrm{y}} \\
{[\mathrm{N}]}\end{array}$ & $\begin{array}{c}\mathrm{F}_{\mathrm{z}} \\
{[\mathrm{N}]}\end{array}$ & $\begin{array}{c}\mathrm{P}_{\mathrm{c}} \\
{[\mathrm{W}]}\end{array}$ & $\begin{array}{c}\mathrm{M} \\
{[\mathrm{Nm}]}\end{array}$ & $\begin{array}{c}\mathrm{T} \\
{\left[\mathrm{C}^{\circ}\right]}\end{array}$ \\
\hline $\mathrm{A}$ & 1 & 150 & 0.24 & -265.2 & -89.1 & 38.3 & 649.3 & 11.4 & 784.9 \\
\hline \multirow{6}{*}{$\mathrm{B}$} & 1 & 150 & 0.8 & -1073.3 & -290.4 & 967.4 & 2615.4 & 46.0 & 862.6 \\
\cline { 2 - 10 } & 2 & 100 & 0.4 & -673.3 & -238.3 & 589.0 & 1075.5 & 28.4 & 836.4 \\
\cline { 2 - 10 } & 3 & 100 & 1.2 & -1509.6 & -394.0 & 1324.2 & 2433.6 & 64.2 & 826.9 \\
\cline { 2 - 10 } & 4 & 200 & 0.4 & -629.7 & -199.2 & 554.0 & 2016.4 & 26.6 & 816.7 \\
\cline { 2 - 10 } & 5 & 200 & 1.2 & -1525.2 & -369.3 & 1355.8 & 4939.6 & 65.2 & 960.9 \\
\cline { 2 - 10 } & 6 & 100 & 0.8 & -1058.1 & -313.6 & 948.1 & 1745.8 & 46.1 & 770.6 \\
\cline { 2 - 10 } & 7 & 150 & 0.4 & -618.6 & -208.0 & 560.3 & 1524.7 & 26.8 & 759.2 \\
\cline { 2 - 9 } & 8 & 150 & 1.2 & -1488.8 & -383.1 & 1337.2 & 3691.8 & 65.0 & 876.6 \\
\cline { 2 - 9 } & 9 & 200 & 0.8 & -1057.5 & -288.7 & 952.4 & 3490.2 & 46.1 & 878.2 \\
\hline
\end{tabular}




\section{DISCUSSION}

Compared to the conventional Insert A (Figure 4), the machining time for the new cutting tool decreased almost always (except for one value) with the chosen parameter pairs of the adjusted process parameters (where we increased the feed by 1.6-5 times and the cutting speed is varied in the range of 100-200 $\mathrm{m} / \mathrm{min}$ ). Therefore, from the point of view of productivity, the resulting values are more favourable than the current values in 8 of the 9 cases based on the time spent on machining. The rate of decline is more than $80 \%$ compared to the current machining time at the highest feed and cutting speed.

The following conclusions can be drawn after the analysis of the cylindricity and roundness errors. Practically, unfavourable values are measured in every case on the surfaces machined by the octagon insert. This phenomenon can be explained by the simulated cutting force values. In Table 4 the cutting forces are much higher for Insert B compared to the simulated force values for the rhombic Insert A. The increase of the cutting force components does not cause a problem up to a specified value, since we are analysing the rough machining. Until the allowance for the finish grinding is large enough to remove the accuracy errors from the previous procedure, then the prescribed accuracy parameters can be held. However, if the resultant accuracy error from the cutting force increase reaches a limit, the grinding allowance must be increased. In this case the machining time for grinding also increases, thus the calculated gain in time in Figure 4 decreases, or even turns into a loss.

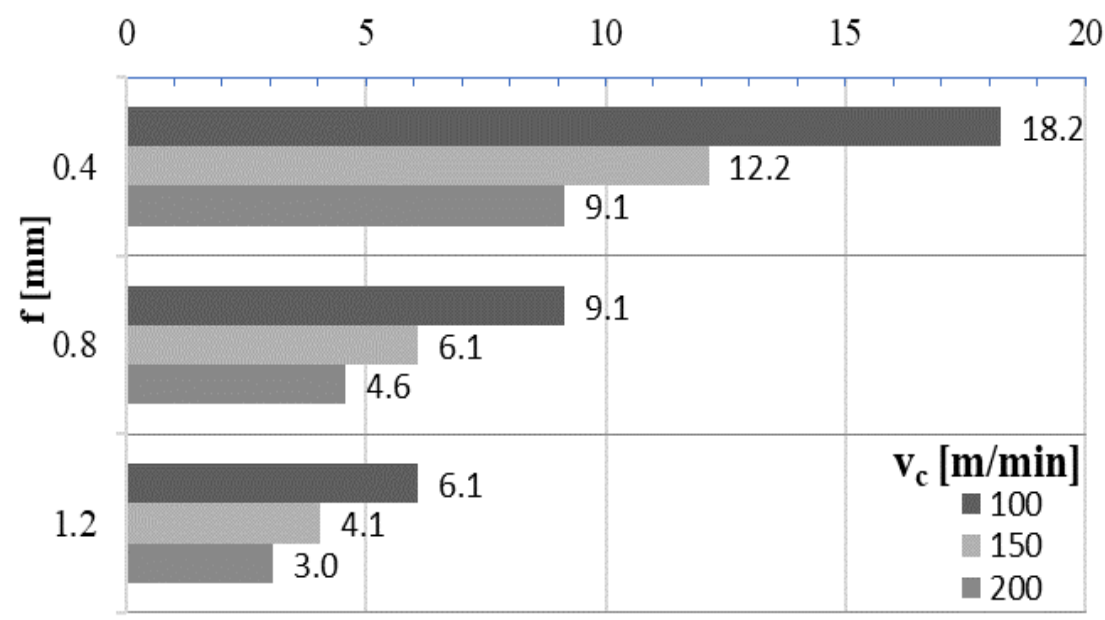

Figure $4 a$ - The machining times for Insert B 


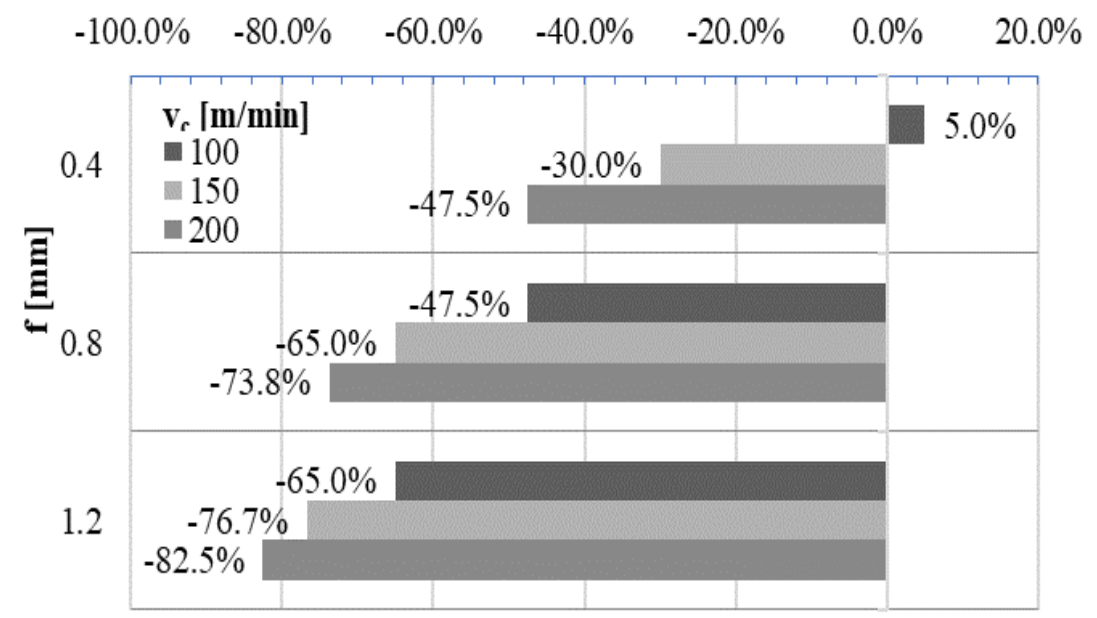

Figure $4 \mathrm{~b}$ - The comparison of machining times of Insert B and Insert A

Our evaluation is shown in Figure 5. Overall, we determine, that Setup 2 (+) should be avoided, because it increases the machining time in all circumstances. The grinding allowance must be increased for Setups 3, 4, 5, 8 and 9 (X). The removal of this added material increases the finish time, therefore these setups are not advised. Setups 1, 6 and $7(\mathbf{O})$ can be used to replace the standard turning insert, since the accuracy error is lower than the material to be removed in grinding $(0.05 \mathrm{~mm})$.

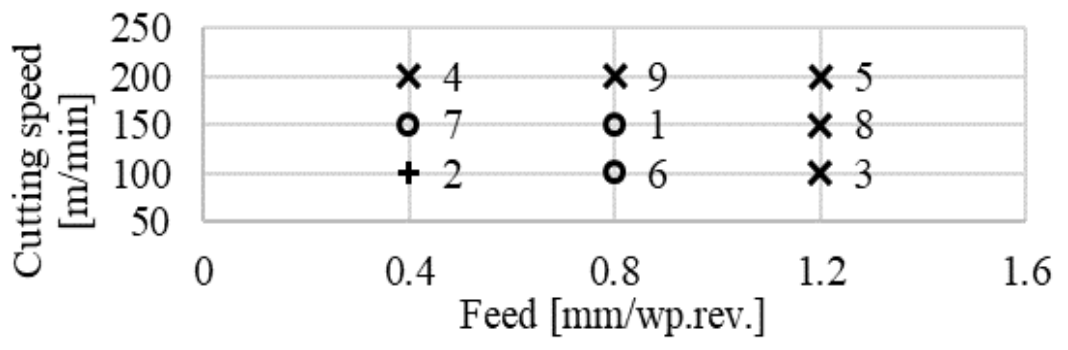

Figure 5 - Recommended parameter-pairs 


\section{SUMMARY}

Accuracy analysis is carried out on surfaces machined by a novel cutting tool, which allows the adjustment of high feed rates. The effect of the cutting data was analyzed on the cylindricity and roundness of the machined surface. The basis of our comparative study was the achievable quality of parts machined with standard cutting tools and parameters in typical industrial environment. Due to the high chosen feed, cutting force alteration was also studied to analyse the rigidity of the mechanical system on the machine tool, which was carried out by Finite Element Method analysis. The chosen parameter pairs were assessed for their suitability to replace the conventional technology. Further analyses are necessary to evaluate the application field of the novel cutting insert and the fulfilment of the quality requirements.

\section{ACKNOWLEDGEMENT}

Project no. NKFI-125117 has been implemented with the support provided from the National Research, Development and Innovation Fund of Hungary, financed under the K_17 funding scheme.

The described study was carried out as part of the EFOP-3.6.1-16-00011 "Younger and Renewing University - Innovative Knowledge City institutional development of the University of Miskolc aiming at intelligent specialisation" project implemented in the framework of the Szechenyi 2020 program. The realization of this project is supported by the European Union, co-financed by the European Social Fund.

References: 1. Bartarya, G., Choudhury S.K.: State of the art in hard turning, International Journal of Machine Tools and Manufacture, 2011; 2. Kandrac, L., Maňková, I., Vrabel, M.: Cutting edge preparation in machining processes. Scientific Letters of Rzeszow University of Technology Mechanics. 30. 149-159, 2013; 3. Kundrák, J.: Alternative machining procedures of hardened steels, Manufacturing technology 11, 32-39; 4. Kundrák, J., Karpuschewski, B., Gyani, K., Bana, V.: Accuracy of hard turning, Journal of Materials Processing Technology, 2008; 5. Byrne, G., Dornfeld, D., Denkena B.: Advancing Cutting Technology. CIRP Annals 52(2), pp. 483-507, 2003; 6. Kundrák, J.: The scientific principles of increasing the effectiveness of inner surfaces cutting with CBN tools. Harkov, p. 368, 1996; 7. Kundrák, J., Mamalis, A.G., Markopoulos, A.: Finishing of hardened boreholes: Grinding or hard cutting? Materials and Manufacturing Processes 19(6) pp. 979-993., 2004; 8. Mamalis A.G., Kundrak J., Gyani K.: On the dry machining of steel surfaces using superhard tools. International Journal of Advanced Manufacturing Technology 19: (3) pp. 157-162., 2002; 9. Zebala, W.: The influence of tool stiffness on the dimensional accuracy in titanium alloy milling. Key Engineering Materials Vol 686, pp 108-113, 2016; 10. SUMITOMO ELECTRIC HARTMETALL

GMBH:

High

Feed

Turning. 
https://www.sumitomotool.com/products/details/high-feed-turning/, 2019; 11. Taylor Hobson: Exploring Roundness. Taylor Hobson Ltd, p.105, 2011.

\author{
Янош Кундрак, Іштван Штанковіч, \\ Мартіна Гевай, Мішкольц, Угорщина
}

\title{
ПОРІВНЯЛЬНИЙ АНАЛІЗ РІЖУЧИХ ПЛАСТИН СВN З РІЗНИМИ ГЕОМЕТРІЯМИ РІЗАЛЬНОЇ КРАЙКИ
}

\begin{abstract}
Анотація. $У$ даній роботі узагальнені результати експериментальних розробок нових ріжучих пластин зі спеціальною геометрією і позиціонуванням для обробки загартованих поверхонь. Конструкиія державки інструменту і ріжучої пластини дозволяє збільшити значення застосовуваної подачі при чистовому точінні. Експерименти проводяться при збільшеній подачі в прочесі токарної обробки, і результати порівнюються з вживаною в даний час звичайною технологією токарної обробки. Незважаючи на те, щяо шліфування, як відомо, забезпечує хорошу якість поверхні, набагато більш висока швидкість видалення матеріалу може бути досягнута при жорсткому точінні, в той час як правильно обрана за формою ріжуча пластина може виробляти таку ж або кращу шорсткість поверхні. Ще однією перевагою є те, що численні операції можуть бути виконані илляом тонкого точіння одним ріжучим інструментом $і$ з однісї установки. У даному дослідженні були застосовані дві ріжучі пластини CBN під час чорнової обробки. Стандартний інструмент, який використовується до сих пір (ромбічна форма з кутом при вершині 80), $і$ новий ріжучий інструмент, восьмигранної форми, в якому кути заокруглені, тому сторони восьмикутника ніби складаються з круглих секцій. Після проведення експериментів по різанню із заданими параметрами процесу були виміряні параметри точності (ииліндричність та округлість). Моделювання для аналізу сил різання проводилося з тими ж значеннями. У порівнянні зі звичайною вставкою час обробки новим ріжучим інструментом зменшувався майже завжди (за винятком одного значення) з вибраними парами скоригованих параметрів прочесу (де збільшили подачу в 1,6-5 разів і швидкість різання варіювалася в діапазоні 100-200 м/хв). Отже, з точки зору продуктивності, отримані значення є більш сприятливими, ніж поточні значення в 8 з 9 випадків.
\end{abstract}

Ключові слова: обробка загартованих поверхонь; ріжучі пластини; точіння; шорсткість; сили різання; моделювання. 